\title{
HEALTHWASHING \\ RHETORICAL TROPES IN HEALTH-POSITIONED PACKAGED GOODS
}

\author{
By \\ Lori Kainu Fischer \\ Bachelor of Applied Science, Food \& Nutrition, Ryerson University, 1998
}

\author{
A Major Research Paper \\ presented to Ryerson University \\ in partial fulfillment of the \\ requirement for the degree of \\ Master of Professional Communication
}

Toronto, Ontario, Canada, 2021

(C) Lori Kainu Fischer, 2021 


\section{AUTHORS DECLARATION FOR ELECTRONIC SUBMISSION OF AN MRP}

I hereby declare that I am the sole author of this MRP. This is a true copy of the MRP, including any required final revisions.

I authorize Ryerson University to lend this MRP to other institutions or individuals for the purpose of scholarly research.

I further authorize Ryerson University to reproduce this MRP by photocopying or by other means, in total or in part, at the request of other institutions or individuals for the purpose of scholarly research.

I understand that my MRP may be made electronically available to the public. 


\begin{abstract}
The current scope of research in consumer-packaged goods has focused primarily on how packaging design is structured to differentiate itself from its competition with the ability to grasp a consumer's attention in mere seconds. The communicative effects of packaging research span the elements of design as they influence the perception of product attributes and expected consumer experiences. This major research paper explores which elements of packaging design are used in health-positioned products in consumer-packaged goods in Canada and how these elements of design are leveraged to craft a narrative. The framework of packaging design elements and implications from past research is used to support the findings and provide critical analysis in conjunction with the content analysis conducted on two well-established healthpositioned food brands in Canada, Presidents Choice Free From and Presidents Choice Blue Menu.
\end{abstract}




\section{ACKNOWLEDGMENTS}

It has been a great privilege to undergo this graduate program at Ryerson University.

I would like to express my gratitude toward Jessica Mudry, for her guidance and supervision. Her willingness to share her expertise and provide valuable advice contributed immensely to the completion of this research project. And I would like to thank my second reader Carolyn Kane for her insightful and thought-provoking feedback that helped to round out my research.

Finally, to my caring, loving, supportive partner Jason and my daughter Quinn, who kept me motivated with her sweet notes of encouragement, my heartfelt thanks and gratitude for your support throughout this past year. 


\section{Table of Contents}

AUTHORS DECLARATION FOR ELECTRONIC SUBMISSION OF AN MRP ................................. ii

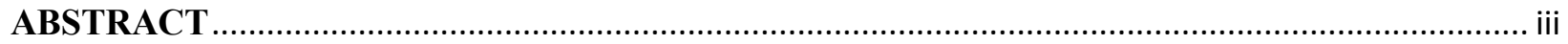

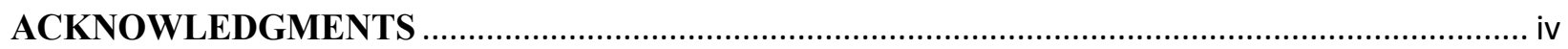

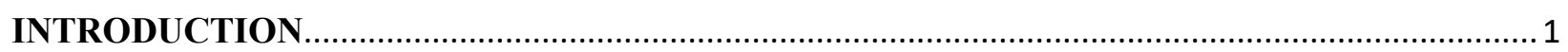

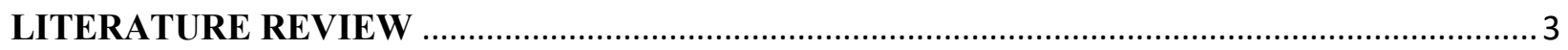

Communicative Effects of Packaging .............................................................................................

Elements of Packaging Design that Influence the Narrative ............................................................... 4

Communicative Elements in Health-Positioned Packaging Design ................................................. 10

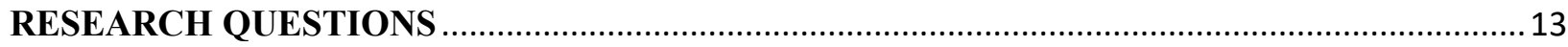

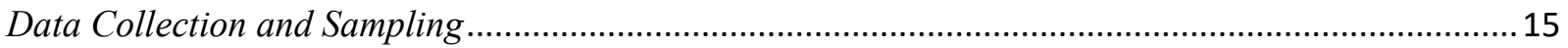

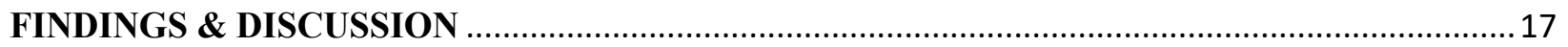

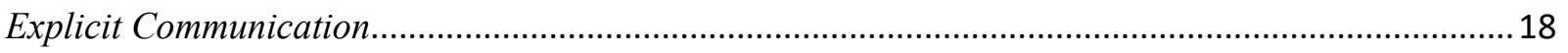

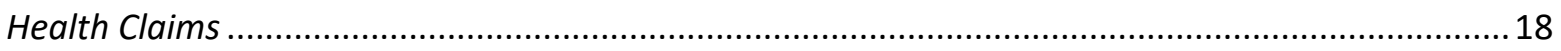

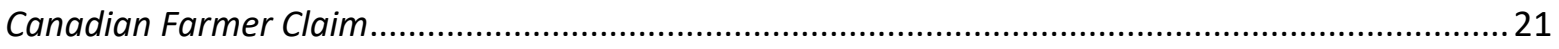

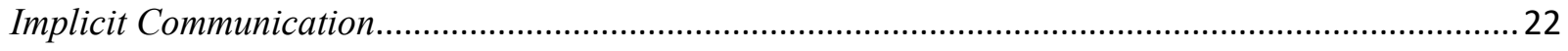

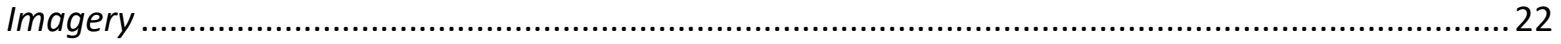

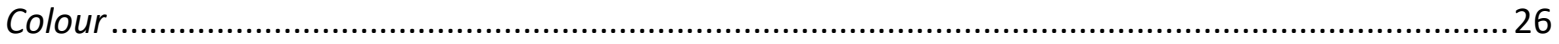

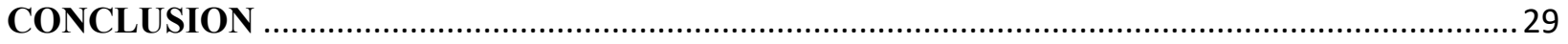

LIMITATIONS \& CONSIDERATIONS FOR FUTURE RESEARCH ........................................ 31

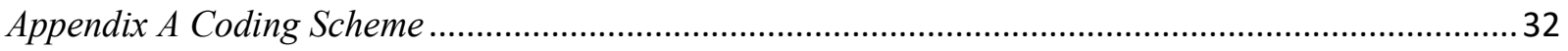

Appendix B: President's Choice Blue Menu Front Panel Design Breakdown .....................................35

Appendix C: President's Choice Free From Front Panel Design Breakdown - With Landscape Image

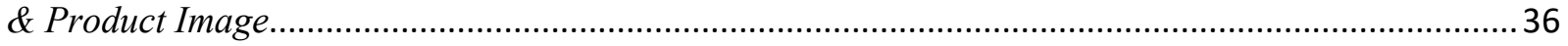

Appendix D: President's Choice Free From Front Panel Design Breakdown - With Human Image ... 37

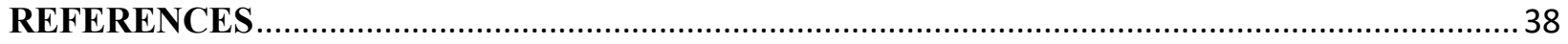




\section{INTRODUCTION}

With the combined efforts of marketing, graphic design and engineering, consumer food packaging has evolved well beyond a mechanism for simply wrapping or protecting goods. Packaging provides a physical space that represents the brand and is used as a core communication tool (Garber et al, 2000). Product packaging is one aspect besides price and brand that influences consumer choice (Underwood et al, 2001). Packaging plays a role to inform, persuade, and connect to the consumer to drive sales and category share. Food companies employ many packaging strategies and studies are primarily focused on understanding what techniques used in packaging are effective and why.

Packaging as a communication tool leverages various elements used in design to craft a narrative to inform and persuade (Rundh, 2016). Characteristics such as, colour, image, linguistic choices, and texture are all used in a variety of ways and combinations to represent the brand message, and prompt assumptions that are made on the contents within the packaging, such as the quality, taste, and health of the product. These characteristics are both explicit, such as the actual claims made on packaging but also implicit using colours and images to strengthen the connection between the consumer and brand.

As consumers demand healthier options across a broad spectrum of food categories (Neilson, 2016), characteristics that specifically prompt healthy associations line our grocery store shelves. "Healthier" provides a lot of flexibility and interpretation. How we define health can be a very individual perspective, even the WHO gives a wide berth to the definition of health, "Health is a state of complete physical, mental and social well-being and not merely the 
absence of disease or infirmity" (WHO, 1948). And there is no shortage of experts to tell us how to achieve this. Considering this, consumer packaged goods companies leverage the trends in our behaviour to model their products and influence purchasing. But like the viceroy butterfly who uses Batesian mimicry, a method of emulating another species visual attributes for their personal benefit of survival, the characteristics used to associate health may only be a form of packaging mimicry, used to seduce the consumer for corporate benefit.

There are many studies on packaging trends in general mostly from the perspective to attract or differentiate at the point of sale. However, since the focus of this research is consumer packaging in the health-positioned category and the characteristics that form the narrative from both an explicit and implicit perspective, the studies with the most relevance will be referred to as appropriate. 


\section{LITERATURE REVIEW}

The literature review reflects the body of research focused on elements of consumerpackaged goods design and how those elements are used for their communicative effect. The following categories represent the relevant themes from the review that contribute to an evergrowing body of knowledge regarding the impact of packaging on consumer perception and understanding. These themes include (1) the overall communicative effects of packaging from a holistic perspective, (2) the explicit and implicit elements of design and their individual impact, and (3) the communicative effects of the design elements within the health-positioned product packaging category.

\section{Communicative Effects of Packaging}

Food packaging was once simply a functional component of food storage and transport, fashioned from materials readily found in nature, woven fibers of grass, the organs of animals, carved crevasses of wood (Jones, 2016). And although the functional components of packaging are still highly relevant albeit vastly improved with modern materials, advancements in packaging technology have focused primarily on food quality and food safety, allowing for improved logistical flexibility in our globalized world (Jones, 2016). Although these functional elements of packaging alone provide a level of communication regarding handling and storage, the focus of this literature review will be the communicative effects of the design elements of consumer-packaged goods. Packaging, as an extension of the brand, when trust is established, has a unique relationship with the consumer as it has the ability to reflect our own self-identity and personal brand (Underwood, 2003). This makes packaging a powerful communicative tool 
(Underwood, 2003) as brands attempt to attract the consumer, differentiate themselves from their competition, and drive consumption.

The field of research in consumer packaging focuses primarily on the understanding surrounding the use of packaging as a vehicle for communication and given that $73 \%$ of purchase decisions are made at the point of purchase (Connolly, 1996), with approximately 50\% of those purchases being unplanned (Philips et al, 1993) and 90\% of consumers making a purchase only having looked at the front of the package (Clement et al, 2007), makes this medium arguably the most significant for communication in consumer goods (Behaeghel, 1991).

As demonstrated in previous research, consumer packaging is used to communicate the anticipated experience a consumer is likely to have with the product (Killip, 1997) and thus plays a role in influencing the consumer's perceptions of the product (Rettie, 2000). But consumers are savvy and when information portrayed on packaging appears inconsistent or deceptive the relationship with the consumer is fractured as trust is compromised (Underwood et al, 1998). These negative associations can be avoided through transparency in the packaging message through a communicative competence framework, fostering a better relationship between the product and consumer (Underwood et al, 1998). This transparency should align the packaging characteristics with the actual product quality and value to circumvent disappointment by the consumer (Kirwan et al, 2003).

Elements of Packaging Design that Influence the Narrative

Although communicating through storytelling is a powerful tool often used in branding, the limitations of storytelling are bound by the physical size of the package (Solja et al, 2018). Studies have shown that information presented in the form of stories can trigger a narrative 
processing response versus information presented in a list format, which conversely triggers an argumentative processing response (Adaval \& Wyer, 1998). In a narrative processing response, consumers are less likely to be critical of the information provided and have a more positive association (Edson, 2004). Regardless of the footprint available on consumer packaging, recent research indicates that information on package presented in a short story format, with a plot, characters, and theme, proved to garner positive consumer perceptions in comparison to packaging that presented the key pieces of the branded story in an attribute list format. (Solja et al, 2018). The study was conducted in a controlled format by which potential consumers were exposed to the types of packaging that either included a short story, included the key pieces of information in a list format or included a packaging with no brand story at all (Solia et al, 2018). However, since this was not conducted in a grocery setting, where the actual point of purchase activity would compete within a much more competitive product set, and where decisions are often made within considerable time constraints (Hoyer, 1984), in some categories less than one second (Milosavljevic et al, 2011), it leaves room to question the actual impact placing a short story on the package would have. However, the brands story can be communicated in other ways through the packaging framework, specifically through verbal cues such as product attribute claims, or visual cues such as an imagery or colour.

Studies often separate packaging into two specific areas of design, graphic and structural. Graphic elements include colour, images, and typography and the structural elements include the size and shape of the container or the packaging material (Ampuero et al, 2006). However, for the purpose of this research paper, the elements of design are split into explicit and implicit communication or verbal and visual components (Kauppinen-Raisanen et al, 2014). 
Explicit elements of packaging refer to direct or obvious factors that influence the perceived perception of the product. For example, a product claim is an easy-to-process piece of information about a product that influences the perceived quality or experience of a product (Stokes, 1985). Although product claims provide communication to the consumer about the benefits or attributes of the product, Mitchell and Papavassiliou studied the effects of multiple verbal cues and suggest packaging claims when used in abundance cause consumer confusion (Mitchell et al, 1999) as it can overload the consumer's ability to process easily. The outcome of consumer confusion is the potential for overall frustration and the risk of purchase abandonment (Mitchell et al, 1999).

The use of multiple product claims may not be the only trigger for consumer confusion. Mitchell and Papavasiliou also identify terms used in health-positioned products that are somewhat ambiguous or misleading but valuable as they garner attention, they use the example of the claim 'light' which, in the product they reference, had no specific relation to any health related factor such as reduced caloric, fat content or alcohol content, rather it was referring to the colour of the product (Mitchell et al, 1999). Other acceptable and established definitions for 'light' include the sensory characteristics of the product such as flavour or taste. In all cases either the sensory characteristic or nutritional benefit must occur on the package with the claim. Regardless, because there isn't one specific regulated meaning for the word light, it may not only be misleading it can also create a sense of confusion if not frustration for the consumer. Their study points to the need for legislation to aid in accurate consumer information that is widely understood to drive further transparency and avoid consumer confusion (Mitchell et al, 1999).

Along the same lines of transparency in packaging communication, country of origin is another explicit element of product design and one which is strictly legislated for use in Canada. 
However, as research demonstrates, referencing a particular Nation on packaging can, in some cases, be leveraged as a product attribute (Michell et al, 1999). A great example of this is Greek yogurt. Greek yogurt, as known in Canada, refers to the process of straining out whey (Hines, 2019) resulting in a very thick final product. Although the practice is thought to have originated in Greece, it was widely adopted by North American companies. Yet the use of Greece in the product name can lead the consumer to perceive a particular product experience. The use of these claims in product packaging can mislead the consumer or establish beliefs about the product that is inaccurate (Michell et al, 1999).

Although most explicit claims on packaging require a level of legislative fidelity to overcome consumer confusion or mistrust, it is clear there are many tactics in packaging design that take advantage of the ambiguity of language.

The efficiency of consumers to process explicit claims have been studied from a cognitive perspective. Applying the effects of the well-studied and validated concept of brain laterality, "functions are performed by distinct regions of the brain" (Guy-Evans, 2021), in marketing communication, Rettie and Brewer analyzed consumer recall of packaged goods (Rettie et al, 2000). Their study found that when the verbal cue was positioned on the right side of the packaging consumers processed the information most efficiently (Rettie et al, 2000). In contrast, images were more easily processed by consumers when they were placed on the left side of the packaging (Rettie et al, 2000).

Where explicit cues in packaging refer to information that is clear and obvious about its meaning, implicit cues are more of an abstract reference that when used in the right context make sense to the consumer (Karjalainen, 2007). Through much of the research that touches on colour and imagery, it is widely accepted that colour and imagery are tools used to differentiate 
products in the competitive consumer packaged goods landscape (Underwood, 2003), thus creating a competitive advantage (Nancarrow et al, 1998). Images are most often cognitively processed before the explicit content by the consumer and can provide context to support the verbal cues (Houston et al, 1987). Additional research explored the use of metaphors on consumer packaging as visual cues to connect perceptions of a brands personality and provide greater context to the verbal or written product information (Rompay et al, 2014). Here the researchers used a series of studies that exposed participants to packaging through advertising campaigns with both ambiguous metaphors and products that combine ambiguous metaphors with verbal product information. The results suggested that ambiguous metaphors along with product information were more highly appreciated and drove higher rates of brand excitement (Rompay et al, 2014).

Cognitive processing of images in further studies suggest information presented in pictures aids in ability to learn quickly (Alesandrini, 1983), as it facilitates incidental learning (MacInnis et al, 1987), learning that is unintentional. Ultimately research supports the hypothesis that images on products increase consumers' attention compared to products with no image and is a significant contributor to consumer's purchase intent (Underwood et al, 2001). Research also indicates that any negative association between imagery and consumer perception is attributed to poor alignment of the image with the contents of the package (Fernqvist et al, 2015). In food-related product research, high quality, vivid images of the product contribute to the consumer perception of how a product feels, tastes, and smells (Underwood et al, 2002), which is a critical method of communicating through packaging as it contributes to the anticipated experience of the product. 
As favourable as images are on packaging, colour has also been found to be a commanding characteristic in packaging as it can garner consumer attention and affect product decision-making (Kauppinnen-Raisanen, 2014). Studies have found that colour in consumerpackaged goods can be an indicator of product quality (Garber et al, 2000). Additional research supports the thesis that colour communicates product attributes such as the anticipated experience of the product from a taste and quality perspective, as well as the perceived benefits of the product (Kauppinnen-Raisanen et al, 2010). Research conducted by Satyendra Singh, found that 62-90 percent of consumer decision about a product is based on colour alone (Singh, 2006).

The implicit element of colour in packaging design can elicit emotional reactions (Madden et al, 2000), this is otherwise defined in research as voluntary attention, triggering stored memories of related colours (Kauppinen - Raisanen, 2014). Colour carries a strong emotional load, and as such, can lead to a faster consumer response times to packaging than the verbal cues or imagery (Kauppinen - Raisanen, 2014). Similar to the study of voluntary attention is the concept of cognitive associative learning (Grossman et al, 1999). Cognitive associative learning connects two variables together and embeds them in our memory. This use of associative cues is widely leveraged in packaging design as evidenced by colour-coding that often appears within product categories (Tutssel, 2001), for example the use of brown in packaging is ubiquitous in the coffee category. The study by Hannele Kauppinen-Raisanen, further explores this associative concept in colour related research and extrapolates this communicative link to additional relationships outside the grocery categories, for example green is commonly found in health-positioned products because it is known to signify nature (Kauppinen-Raisanen, 2010). 
Although there is much scholarly interest in colour and packaging, colour appears to be somewhat controversial. Many studies point to the significance of its use, arguable the most significant non-verbal cue in packaging. However, colour trends continue to flex based on a multitude of factors making specific colour choices in packaging and their subsequent emotional load difficult to predict prompting the need for diligent ongoing awareness and re-evaluation of trends (Singh, 2006). In addition, the context or category in which the colours are used in consumer goods are also important to consider as they are often not transferable. However, it has been found that as a tactic introducing a new colour into an otherwise colour blocked category can be an attention-grabbing tactic, especially for consumers open to change and those that lean toward early adoption consumer behaviour (Kauppinen-Raisanen et al, 2010), but additional cognitive processing in this case would be required as they would not be taking advantage of the cognitive associative learning (Grossman et al, 1999).

\section{Communicative Elements in Health-Positioned Packaging Design}

Demand for healthier product options continues to increase as dietary related diseases are on the rise (Chrysochou et al, 2015). As defined by Chrysochou, a health brand is established when an organization intentionally communicates the health perceptions of a brand "explicitly or implicitly" (Chrysochou et al, 2015). The explicit communication of a product positioned as healthy is often guided by legislative requirements, such as the nutrition facts label which breaks down the product's nutrient value by its components or specific health claims or call outs. These verbal elements can become barriers for a brand if the criteria for the claims are difficult to meet (Chrysochou et al, 2015). Combining this perceived barrier in packaging communication with the existing increased consumer resistance in the health category, due to perceived manipulation by brands in health related products (Maibach et al, 1996), implicit communication becomes a 
valuable tool. In the study conducted by Chrysochou, which analyzed the marketing mix strategies employed by corporations of health-positioned products and associated public discourse, he found packaging in this category relied heavily on secondary associations to communicate health primarily with images or symbols (Chrysochou et al, 2015). When verbal health claims were used, he found a single health claim was easier for the consumer to comprehend (Chrysochou et al, 2015), this aligns with the previous research by Mitchell and Papavasiliou where multiple claims contribute to consumer confusion (Mitchell et al, 1999).

In 2018 Alexandra Festila and Polymeros Chrysochou conducted further research to examine the implicit communication in health positioned products (Festila et al, 2018). The researchers used content analysis comparing regular products, or non-health-positioned products and a healthier offering in the same category (Festila, 2018). They studied this through the lens of the graphic elements of colour and images, as well as the structural characteristics of the packaging. The study found that lighter or more natural colour schemes were used in the healthier product offering as well as the use of nature in the packaging imagery (Festila et al, 2018). The health benefits of nature are well studied siting a positive relationship between our exposure to nature and improved health (Cox et al, 2017). More specifically a reduction in blood pressure is tracked when we are experiencing nature, even if that experience is limited to a window view of nature (Hartig et al, 2003). The use of nature imagery on packaging could trigger this cognitive association to health due to the known positive impact that nature has on our health, but also possibly trigger a health halo effect.

The health halo effect is when a product is perceived to be healthy or have additional health benefits, beyond the single characteristic or claim, without specific evidence to support the claim (Magee, 2020). The health halo effect can be achieved both explicitly and implicitly. 
A study using the claim of 'organic' on packaging demonstrated the consumer perception included a multitude of additional health attributes associated with the word organic, suggesting there is a health halo effect associated with that claim (Lee et al, 2013). In addition, the terminology of locally sourced and the associated health halo effects have been studied in the restaurant segment (Bacig et al, 2019). Although there is no specific legislation defining the use of locally sourced, it is often associated with food procured within close proximity to the consumer (Ewards-Jones, et al, 2008). The outcome of this research indicates that the perception of the restaurant with the locally sourced claim was considered to be healthier and more environmentally friendly (Bacig, 2019).

When creating a health narrative, a combination of design elements is most often used (Chyrsochou et al, 2015). Although visual elements such as imagery and colour are noticed more readily and have the ability to elicit emotions, they should also be used along with one or more health claims which helps elevate the communication of health from a more holistic perspective (Chyrosochaou et al, 2015). When a study was conducted to determine a prototypical package of health-positioned products, researchers suggest white packaging is most often leveraged with light or faded shading. Imagery includes nature and a standardized symbol of health, in this case a 'keyhole' label, which is a legislated label of basic health criteria used in Nordic countries. Although one of the limitations of this study is this geographic limitation and associative cultural inferences, it does support the benefit of secondary associative elements in health-positioned packaging. 


\section{RESEARCH QUESTIONS}

The size of the grocery industry in Canada is approximately 84 billion dollars (Blazquez, 2021). The competition on shelf is fierce with $95 \%$ of all product launches estimated to fail (Emmer, 2018), consequently getting share of the market is increasingly difficult. There are only a handful of grocer retailers in Canada controlling the consumer shopping experience, who also prioritize their own private label interests. The pressure is on manufacturers to get their products in store for a chance to survive however, the financial investment to do so is steep. With these pressures price, another significant lever in consumer-packaged goods at the point of purchase and a notable element of product communication, is a difficult and complex element of the marketing mix to manipulate. Packaging then is required to do a lot of heavy lifting. Although legislation in Canada attempts to control the information provided to consumers on pack for the sake of transparency, my interest lies in the latent meaning behind the elements of packaging design that attempt to connect with the underlying values of consumers often at a subconscious

level. Specifically, this research contributes to the body of knowledge on packaging elements of design working in tandem to illustrate a health-positioned narrative in the Canadian consumerpackaged goods marketplace by exploring specific health-related products in Canadian grocery. The aim of these research questions is to extrapolate the individual elements of design, analyzed both independently and in combination to illustrate how these elements fuse into a singular narrative, 'better for you', triggering multiple cognitive associations with health and well-being. 
RQ1: How do elements of packaging design, (colour, imagery, and language) craft a narrative?

The current body of knowledge thoroughly analyzes the impact of the elements used in packaging design on attention and differentiation. The intention of this research question is to evaluate a well-established line of products in the Canadian marketplace through the lens of these elements objectively analyzed by their individual components, identifying patterns in elements that are used in combination and determine how they work together to craft their product story.

RQ2: How does the visual characteristics of the packaging (colour and imagery) reinforce the explicit product claims made on packaging and how do they differ between the two President's Choice product lines Free From and Blue Menu?

The strength of President's Choice in the Canadian marketplace and their leverage over distribution across Canada make their sub-branded product lines Blue Menu and Free From, both positioned in the healthier category, a compelling line of products for analysis and comparative analysis.

RQ3: What are the rhetorical tropes indicated by colour, image and language in the healthpositioned product lines?

Elements of packaging design can become symbolic representations. This research intends to explore what symbols of health are represented through the elements of design specifically in our western consumer culture. 


\section{METHODOLOGY}

\section{Data Collection and Sampling}

For this research project, two Canadian sub-brands from the President's Choice brand of products, Blue Menu and Free From were chosen for analysis. Presidents Choice is the private label brand of Loblaws, the largest grocery retailer in Canada with 27\% market share as of 2019 (Coppola, 2021). The Presidents Choice line of products were first introduced in Canada in 1984 inspired by Marks \& Spencer's private label strategy in the UK (Boyle, 2003). Presidents Choice is considered one of Canada's most trusted brands (Kolm, 2016). With over 600 product launches annually (Kolm, 2016), Presidents Choice responds to market trends and creates products that resonate with diverse consumer lifestyles including health and wellness. The Blue Menu and Free From line of products are positioned in the healthier choice's category validated by both the brands claim of targeting a healthy lifestyle and by the presence of health claims that meet a specific criterion as determined by the Canadian Food Inspection Agency.

The Free From line of products are focused on the meat category, spanning fresh, frozen, and further processed, therefore I selected products in the protein category from Blue Menu to drive consistency in category representation. The data was collected from the Loblaws Express online grocery shopping website, with screenshots of the front panel used for analysis.

Considering the accessibility of front panel packaging on store shelves and the fact that $73 \%$ of purchase decision are made at the point of sale (Connolly and Davidson, 1996), the front of pack is a critical component in crafting the overall narrative. Even consumers actively seeking specific dietary information spend significantly more time looking at the front panel of packaging and are more influenced by the front panel (Bix, et al, 2015). Overall, a net sample size of 74 front 
panel packages was analyzed, 47 represented the Free From line and 27 represented the Blue Menu line.

A content analysis was conducted for each front panel. Content analysis is a valuable research tool for consumer research used to identify themes, concepts, and patterns in communication (Kassarjian, 1977) and was noted in multiple studies related to packaging design. The reliability and validity of the information amassed from the content analysis relies on characteristics that are objective, systematic and quantitative (Kassarjian, 1977). Therefore, a coding scheme modeled after a packaging study at AARHUS University in Denmark (Chrysochou, 2015), as illustrated in Appendix A was developed to aid the categorization and qualification of the information observed on the front panel and reduce potential bias when evaluating. This coding scheme was modified to reflect the Canadian market and the intentions of this study. Three core categories of information were evaluated (1) health claims, (2) imagery, (3) colour. These categories were further evaluated with the following breakdown (1.1) the presence of a health-positioned claim , (1.2) the actual position of the claim on the packaging, (1.3) the presence of any additional health-positioned claims, (2.1) presence of an image, (2.2) the type of image used (product, flavour cue, human, nature), (2.3) other human related characteristics (name, location, Canadian farmer claim), (3.1) the prominent colour(s), (3.2) the intensity of the colour(s).

The analysis was achieved by evaluating frequencies of design characteristics for each sub-brand, to determine a pattern or theme established individually and the relationship between explicit packaging information and implicit packaging information. Then a comparison of the results was conducted between the two sub-brands to determine their similarities and/or differences in design elements. 


\section{FINDINGS \& DISCUSSION}

The following segment will review the findings of the content analysis for the front panel packaging of the Presidents Choice Free From and Presidents Choice Blue Menu line of products. The following table 3.1, refers to the summary of these results in a comparative analysis of each characteristic and the frequency of which they occurred within their respective sub-brands. This is followed by a further breakdown of these findings illustrated in chart form representing the findings of main elements of packaging communication leveraged with these brands. Included in these findings is a discussion that will explore these key findings in a broader context related to research identified in the literature review.

Table 3-1 Summary of results, distribution between core brands

\begin{tabular}{|c|c|c|c|}
\hline & Total & $\begin{array}{c}\text { PC } \\
\text { Free From }\end{array}$ & $\begin{array}{c}\text { PC } \\
\text { Blue Menu }\end{array}$ \\
\hline Total Products Analyzed & 74 & $64 \%$ & $36 \%$ \\
\hline \multicolumn{4}{|c|}{ Primary Nutrition Claim } \\
\hline Nutritional Claim & $100 \%$ & $100 \%$ & $100 \%$ \\
\hline No Nutritional Claim & & $0 \%$ & $0 \%$ \\
\hline \multicolumn{4}{|c|}{ Claim position } \\
\hline Vertical Top & $97 \%$ & $94 \%$ & $100 \%$ \\
\hline Vertical Middle & $3 \%$ & $2 \%$ & $0 \%$ \\
\hline Horizontal Left & $64 \%$ & $96 \%$ & $7 \%$ \\
\hline Horizontal Middle & $36 \%$ & $4 \%$ & $93 \%$ \\
\hline \multicolumn{4}{|c|}{ Canadian Farmer } \\
\hline $\begin{array}{r}\text { Canadian Farmer } \\
\text { Referenced }\end{array}$ & $36 \%$ & $43 \%$ & $0 \%$ \\
\hline $\begin{array}{r}\text { Canadian Farmer not } \\
\text { Referenced }\end{array}$ & $64 \%$ & $57 \%$ & $100 \%$ \\
\hline \multicolumn{4}{|c|}{ Other Health Claims } \\
\hline Additional Health Claim & $77 \%$ & $81 \%$ & $70 \%$ \\
\hline $\begin{array}{r}\text { No Additional Health } \\
\text { Claim }\end{array}$ & $23 \%$ & $19 \%$ & $30 \%$ \\
\hline \multicolumn{4}{|c|}{ Prominent Colour } \\
\hline White & $39 \%$ & $4 \%$ & $100 \%$ \\
\hline Beige & $61 \%$ & $96 \%$ & $0 \%$ \\
\hline Blue & $36 \%$ & $0 \%$ & $100 \%$ \\
\hline Green & $64 \%$ & $100 \%$ & $0 \%$ \\
\hline \multicolumn{4}{|c|}{ Colour Intensity } \\
\hline Dark / Intense & & $0 \%$ & $0 \%$ \\
\hline Light / Faded & $84 \%$ & $100 \%$ & $56 \%$ \\
\hline Half \& Half & $16 \%$ & $0 \%$ & $44 \%$ \\
\hline & Imag & & \\
\hline
\end{tabular}




\begin{tabular}{|c|c|c|c|}
\hline Presence of Image & $100 \%$ & $100 \%$ & $100 \%$ \\
\hline No presence of Image & & $0 \%$ & $0 \%$ \\
\hline \multicolumn{4}{|c|}{ Product Related Image } \\
\hline Product Image & $59 \%$ & $36 \%$ & $100 \%$ \\
\hline No Product Image & $41 \%$ & $64 \%$ & $0 \%$ \\
\hline \multicolumn{4}{|c|}{ Human Image } \\
\hline presence of human image & $53 \%$ & $83 \%$ & $0 \%$ \\
\hline $\begin{array}{r}\text { no presence of human } \\
\text { image }\end{array}$ & $47 \%$ & $17 \%$ & $100 \%$ \\
\hline \multicolumn{4}{|c|}{ Ethnicity if Human Image used } \\
\hline Caucasian & na & $100 \%$ & na \\
\hline BIPOC & & $0 \%$ & na \\
\hline \multicolumn{4}{|c|}{ Human Names Used } \\
\hline Name Present & na & $81 \%$ & na \\
\hline No Name Present & na & $19 \%$ & na \\
\hline \multicolumn{4}{|c|}{ Canadian Town, Province } \\
\hline $\begin{array}{r}\text { Reference to Canadian } \\
\text { town / province }\end{array}$ & na & $30 \%$ & $0 \%$ \\
\hline $\begin{array}{r}\text { No Reference to Canadian } \\
\text { town/ province }\end{array}$ & na & $70 \%$ & $0 \%$ \\
\hline \multicolumn{4}{|c|}{ Flavour Cue Image } \\
\hline Flavour Cues & $7 \%$ & $4 \%$ & $11 \%$ \\
\hline No Flavour Cues & $93 \%$ & $96 \%$ & $89 \%$ \\
\hline \multicolumn{4}{|c|}{ Image of Nature } \\
\hline Presence of Nature Image & $11 \%$ & $17 \%$ & $0 \%$ \\
\hline $\begin{array}{r}\text { No presence of Nature } \\
\text { Image }\end{array}$ & $89 \%$ & $83 \%$ & $100 \%$ \\
\hline \multicolumn{4}{|c|}{ Image Alone Health Related } \\
\hline Image Health Related & $20 \%$ & $4 \%$ & $48 \%$ \\
\hline Image not Health Related & $80 \%$ & $94 \%$ & $52 \%$ \\
\hline
\end{tabular}

\section{Explicit Communication}

\section{Health Claims}

The health claims represent an explicit or verbal packaging design characteristic. These claims are explicit as they are easy to process pieces of information that are direct and obvious and are positioned to influence the perceived experience of the product, in this case, to establish a level of health associated with the contents. 


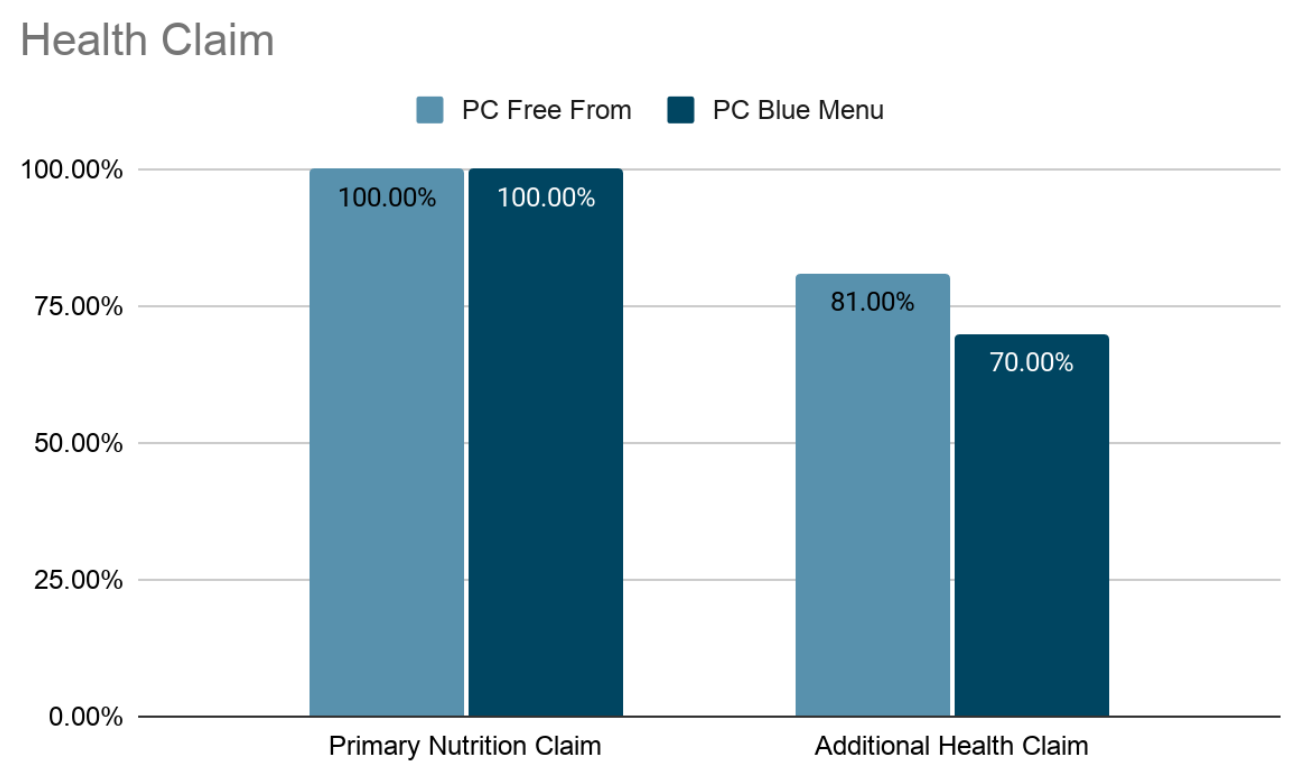

Figure 3-1 Presence of Primary and Additional Health Claim

As Figure 3-1 illustrates, both lines of Presidents Choice products, Free From and Blue Menu, include a primary nutrition claim on every package evaluated. The primary nutrition claim was either a nutrient or a composition claim (antibiotic or hormone claims), approved for use in Canada on consumer-facing food packaging as determined by the Canadian Food Inspection Agency. Although both lines of products often used a secondary claim, this was found more frequently leveraged through the PC Free From products, which resulted in an $81 \%$ occurrence versus PC Blue menu which leveraged an additional claim $70 \%$ of the time.

Previous studies suggest an over-use of product claims on pack can negatively affect the cognitive processing of the explicit claim by eliciting consumer confusion (Mitchell et al, 1999). This would suggest there is some perceived risk in the use of multiple claims which both subbrands often employ. Further studies would be required to confirm the impact of this finding to determine if a threshold for cognitive processing has been surpassed. 
As found in the literature review, the placement of the claim is significant in cognitive processing. As demonstrated in Figure 3-2, both product lines leverage the upper half of the packaging almost exclusively however, the Free From line positions the claim on the left side of the packaging while the Blue Menu favours the middle of the packaging. This strategy for both product lines runs contrary to the research that suggests the most efficient processing occurs when the placement for an explicit claim is on the right side of the packaging (Retti et al, 2000).

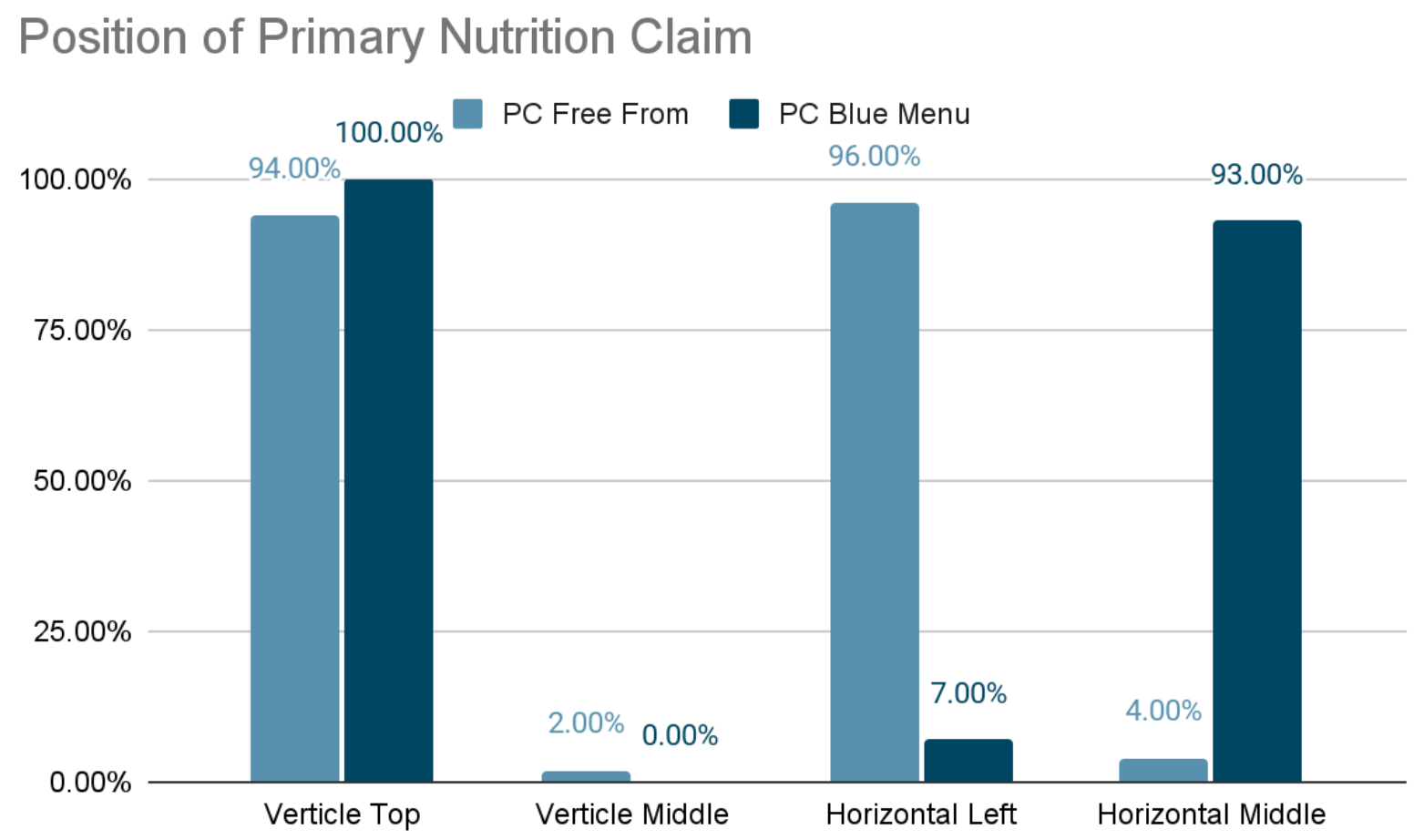

Figure 3-2 Positioning of the Primary Health Claim

Considering the placement of the health claim does not maximize the cognitive processing that can be achieved with an explicit cue leads to an assumption that the additional elements of packaging are working to provide the implicit characteristics of health in support of 
these claims. This renders these explicit claims less significant in their role as a primary driver to communicate the brand's position of health.

\section{Canadian Farmer Claim}

The last element of the verbal cues analyzed was the finding of the explicit use of 'Canadian Farmer' which was found only on the PC Free From product line in $43 \%$ of the packaging analyzed. This is separate and distinct from a Country of Origin claim which is a legislated claim with very specific criteria related to both the manufacturing location and ingredient procurement. This aligns with the existing research that suggests that a country can be used as a product attribute (Mitchell et al, 1999). So although this is an explicit cue, it has an implicit or implied meaning in the case of the PC Free From line. Further segmenting the data associated with the PC Free From product line when the 'Canadian Farmer' verbal cue is used as illustrated in Figure 3-3, we also see additional verbal cues supporting a similar message, the use of a human name and the use of a city or town within Canada. Individually these verbal cues are not that significant, but when used together it reinforces the implied message of supporting local Canadian farmers, and leverages the consumer trend of 'sourced local' or 'farm to table'. Both trends in consumer behaviour that imply reduced processing of food (Massey, 2015) or a healthier option than heavily processed packaged goods. 


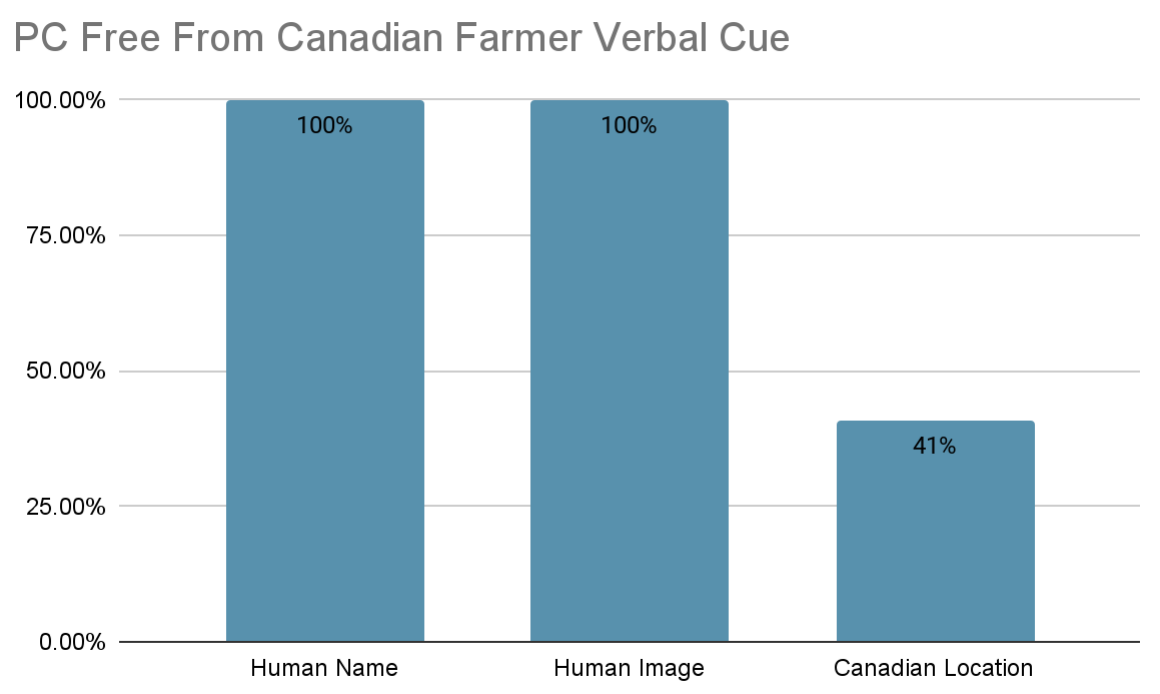

Figure 3-3 Canadian Farmer Verbal Cue and Associated Verbal Cues Used

\section{Implicit Communication}

\section{Imagery}

Imagery is leveraged in both lines of President's Choice products and occurs $100 \%$ of the time on the packaging analyzed. However, the types of imagery used are strategically differentiated between the product lines. As illustrated in Figure 3-4, the PC Blue Menu product line utilizes a product image in every package analyzed. The strategy for PC Blue Menu points to the utilization of appetite appeal by showing a product shot, which is a common strategy in food products to communicate the perceived anticipated experience of the product. However, when this image is analyzed on its own for its association with health, it was perceived to represent health only $48 \%$ of the time. Leveraging appetite appeal with more indulgent, mouthwatering images could be the brand's attempt to overcome the association of healthier products with negative taste perceptions (Raghunathan et al, 2006). 


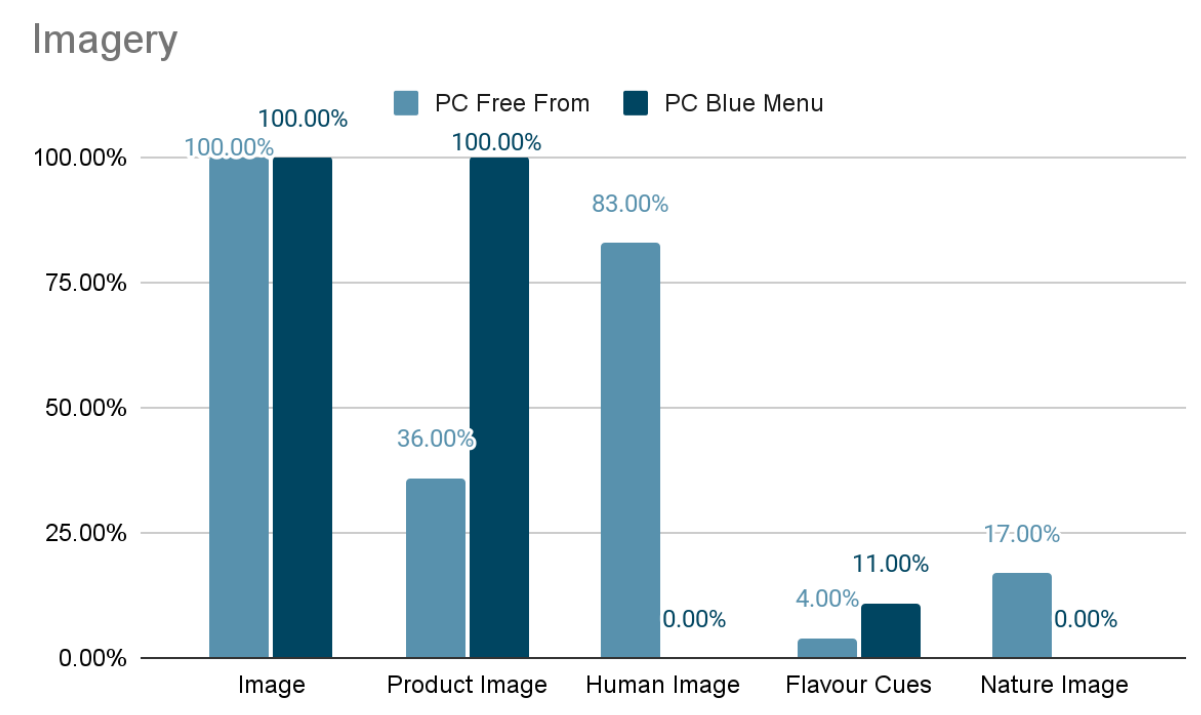

Figure 3.4 Distribution of Imagery on Packaging

The PC Free From products utilized a very polarized image strategy compared to PC Blue Menu. The PC Free From packaging leveraged a human image $83 \%$ of the time and only provided a product image in $36 \%$ of the packaging analyzed. In addition they also utilized an image of nature in $17 \%$ of the packaging analyzed. When further segmenting this data to isolate packaging with a product image as demonstrated in Figure 3-5, a human image was also leveraged in $53 \%$ of the packaging analyzed and a nature image was utilized in $47 \%$ of the packaging analyzed. But its important to note, that a human image and nature image never coincided on any of the Free From packaging analyzed as illustrated in Table 3-5. Which image is used in which product is perhaps determined by the physical size of the print space available. When these images were analyzed for their stand-alone indication of health, the product images were more likely to communicate an obvious perception of health. This perception of health in the product image is based primarily on the known food related health triggers found in the western consumer culture i.e. a whole grain bun or a side salad. This infers that like PC Blue 
Menu, product images were selected to increase appetite appeal which is often perceived less in healthier products (Raghunathan et al, 2006).

The images of a human and those of nature, when analyzed on their own, did not register a specific relationship to health. The human images used did not depict images that are typically associated with a healthy lifestyle in western consumer culture such as individuals wearing active clothing or perception of physical strength as seen in other categories such as vitamins or supplements. Isolating the images alone without any other influences the individuals were very much non-descript and lacked any diverse representation. As well the nature images, which were illustrated drawings of farmland, also did not register specifically as health. However, it could be argued that the known relationship between nature and improved health (Cox et al, 2017), triggers a cognitive association to health.

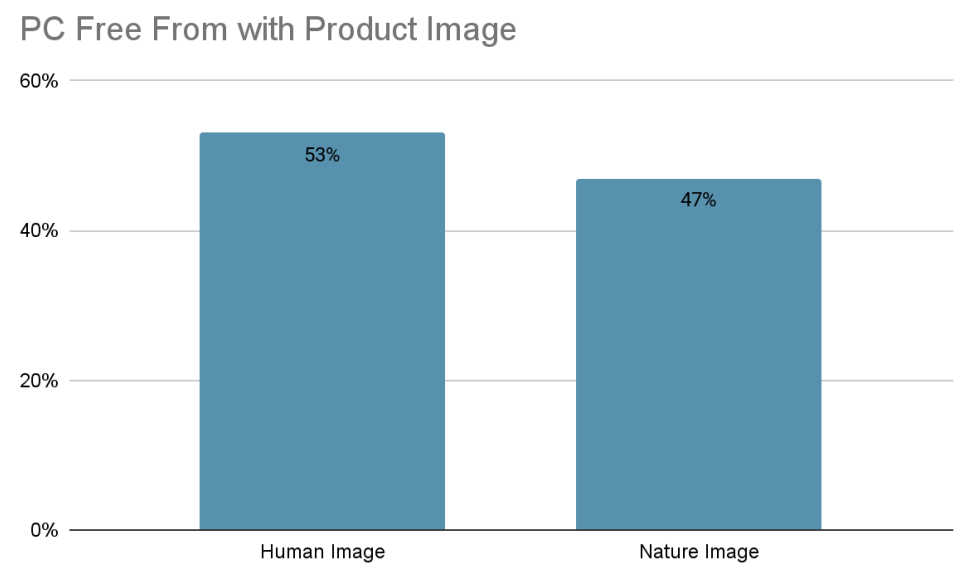

Figure 3-5 Distribution of additional image elements when a Product Image is used in PC Free From 


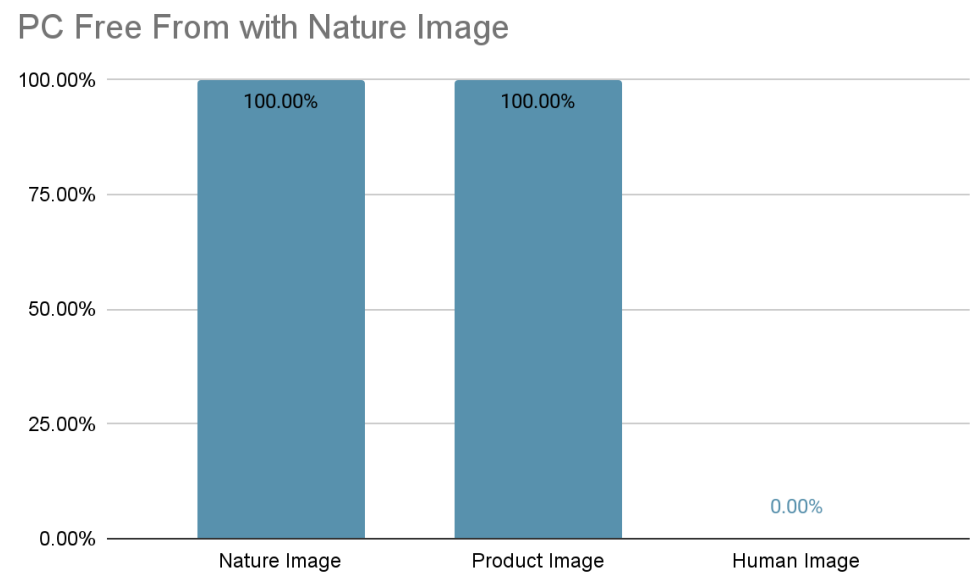

Figure 3-6 Distribution of Image Elements in PC Free From when Nature Image is Present

Ultimately, the lack of health communicated in the imagery used exemplifies the importance of the additional implicit cues and explicit cues used in packaging that work together to communicate the overarching message of health. Figure 3-7 illustrates the distribution of the additional explicit and implicit cues when the data of the human image on packaging is isolated. A person's name is used in $97 \%$ of the packaging analyzed, the claim of 'Canadian Farmer' is used in $69 \%$ of the packaging and a reference to the person's affiliated town or province is leveraged on $36 \%$ of the packaging. These design elements provide a greater context to the consumer as they work in tandem with the human image. This moves the consumer towards the human and natural characteristics of the product reinforcing the implied message of minimal processing. Processed foods are often associated with chronic disease and obesity and are therefore perceived to be less healthy (The Nutrition Source, 2021). This also supports the narrative of the 'local farming' and 'farm to table' consumer trends. 


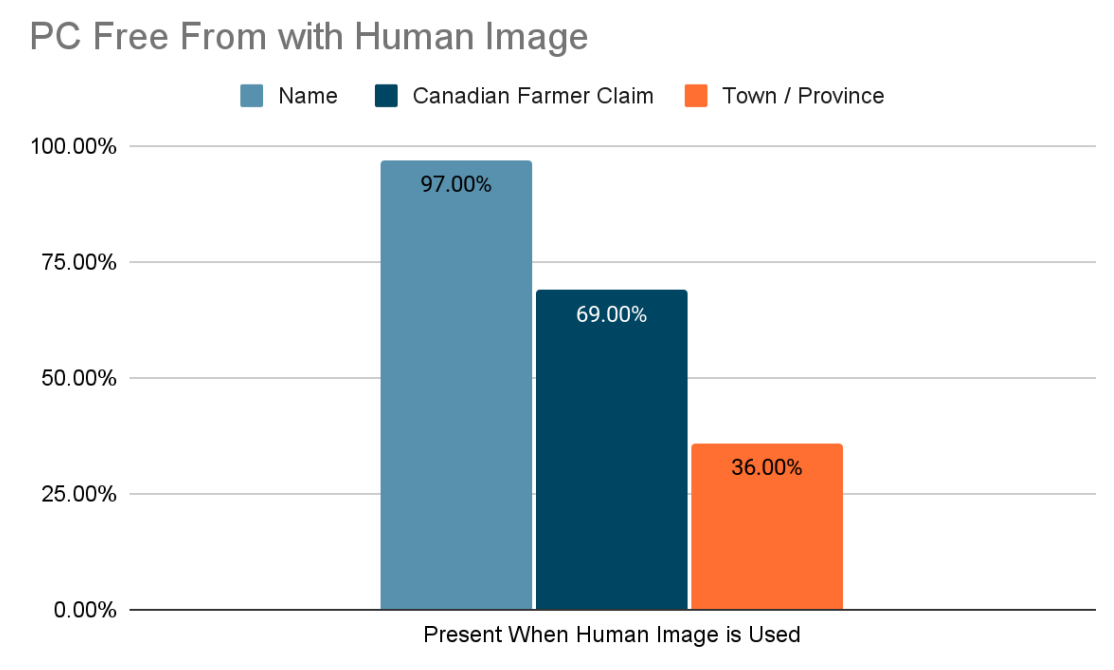

Figure 3-7 Distribution of additional Human Characteristics when a Human Image is used

\section{Colour}

Colour used as an implicit design element, is leveraged by both brands. The primary use of two core colours for each sub-brand of President's Choice packaging creates a colour blocking strategy differentiating the brands. As illustrated in Figure 3-8 PC Blue Menu, to no surprise given its namesake, leverages blue and white colouring on their packaging. The colour intensity varies slightly with an almost even split of the product line leveraging a light and faded intensity to a 50/50 split that moves the packaging colour from dark or intense to light and faded. In contrast the Free From line of packaging analyzed uses a beige and green colour scheme with a consistent intensity registering as light or faded. 


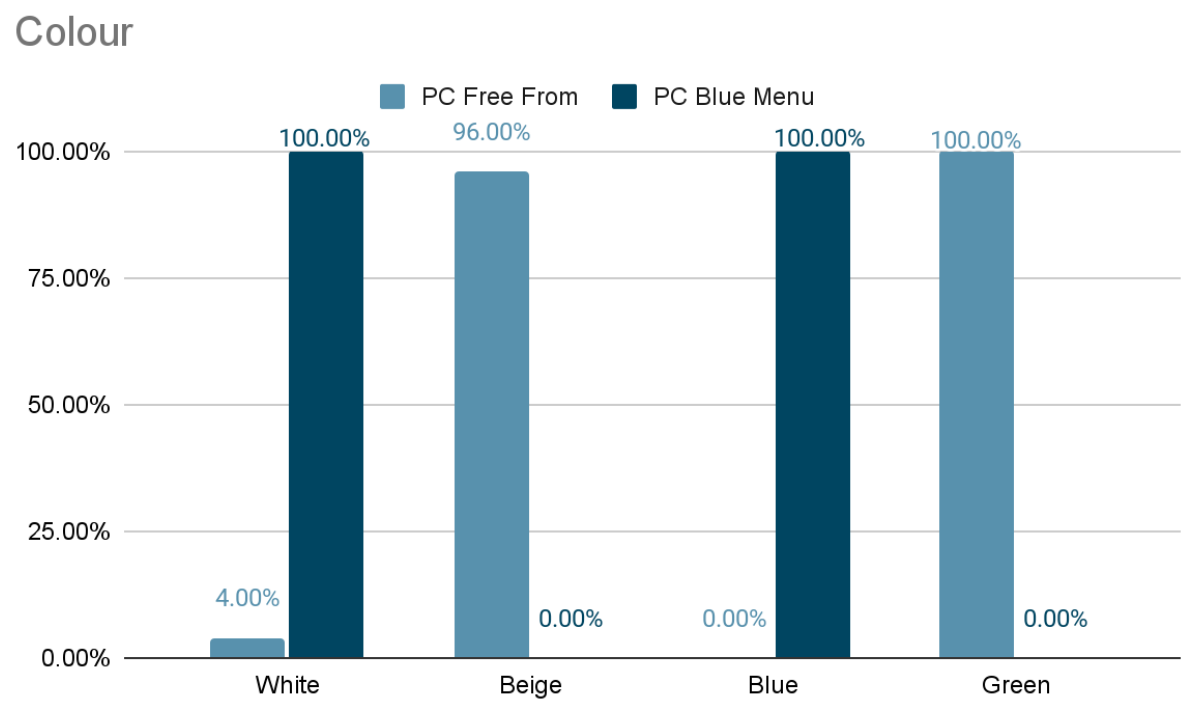

Figure 3-8 Distribution of Dominant Colour

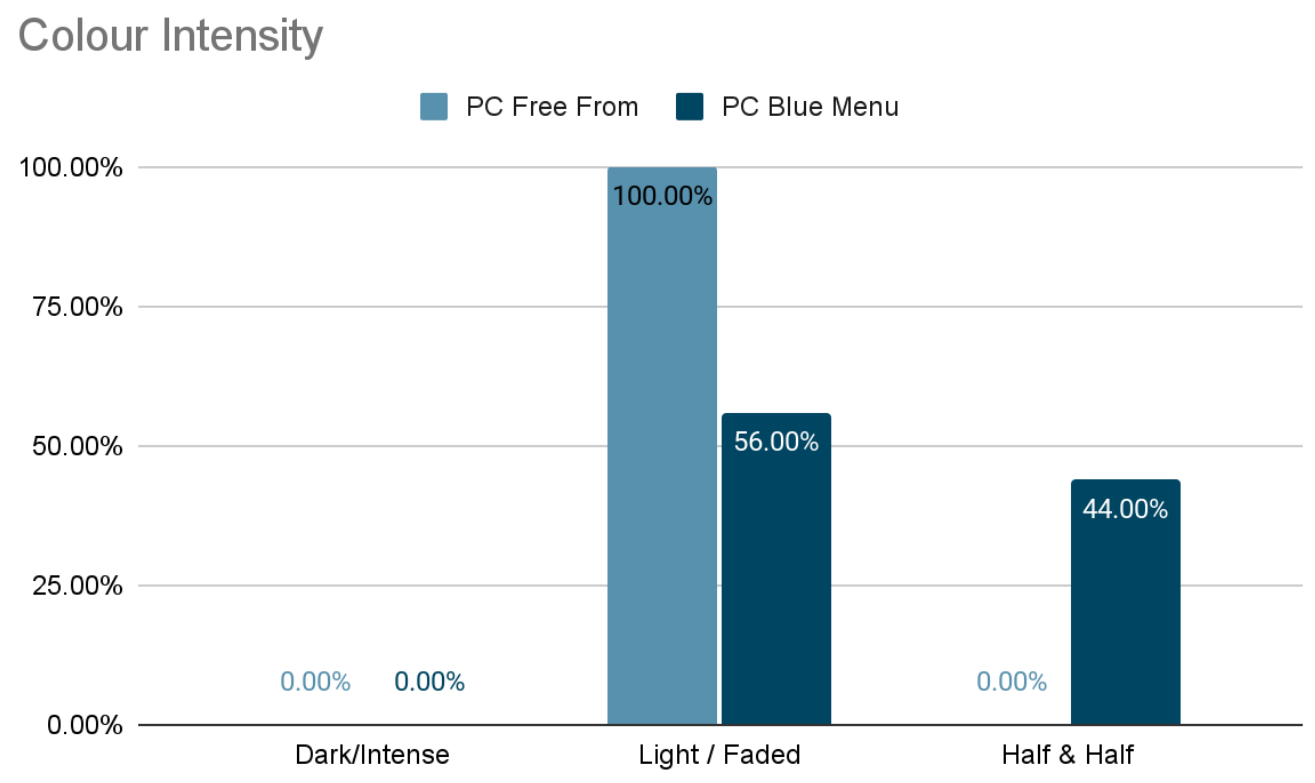

Figure 3-9 Distribution of the Colour Intensity

Although both product lines are positioned in the healthier for you category of products the use of colour differentiates the type of messaging within this category of products, and is the most obvious differentiator of the two product lines. Psychologically, blue is often associated 
with trust and dependability (JohnsBryne, 2017), while white often represents purity and efficiency (JohnsBryne, 2017), but it can also be perceived as sterile (Connnolly, 2018). Therefore, Blue Menu's colour scheme has the power to communicate trust and reliability in their product line through its association related to the values of scientific rigor and testing.

Based on the previously reviewed study by Hannele Kauppinen-Raisanen that explores the communicative link with colour, green is often affiliated with health-positioned products because of their associative affect with nature. Faded green is also known to be associated with nutritious foods and environmentally safe products (JohnsBryne, 2017). Katie Smith, a selfproclaimed internationally known colour expert breaks down the physical response to the colour green which overall has a calming effect on the nervous system (Smith, 2021). However, green also carries potential negative associations, with sickness and nausea (Smith, 2021), this is why historically green was avoided on food packaging because of the potential association with spoilage. But with the increasing focus on the environment in modern Western culture, green has become a symbol for nature and the earth. Earth tones like beige triggers wholesome and allnatural associations (Connolly, 2018). This earthy and natural colour scheme proliferates the organic and natural food sector today (Connolly, 2018), creating cognitive associative learning (Grossman et al, 1999) connecting colours like beige with nature and earth.

The importance of colour to a brands identity is evidenced by the trademark laws in Canada to protect certain colours for exclusive use in a variety of promotional materials including packaging. However, the meaning and psychologic associations of colour vary culturally (Madden, 2000). The context of this study includes the impact of these colours specific to the modern Western culture. 


\section{CONCLUSION}

The results of this content analysis on the President's Choice Free From and Blue Menu sub-brands illustrate the use of various elements of design to craft a narrative rendering packaging a powerful communicative tool (Underwood, 2001). Both brands managed to differentiate themselves while serving an underlying message of health and well-being, although at varying points on the health spectrum using multiple touch points that contribute to cognitive associations of healthy living. The Blue Menu line of products burdens the colour characteristic of its packaging to carry the implicit communication and support the explicit health claims. Nutritional claims are more scientific in nature as they require a structured system of clinical laboratory testing, so the latent meaning of trust, reliability and purity associated with this colour scheme works to support the nutritional benefits from an associative perspective.

Presidents Choice Free From Product line carefully crafts an image of healthy living. Their farm-to-table narrative is supported by the multifaceted design characteristics spanning significant use of visual and verbal cues. Their composition claim of nutrition, in this case the absence of something (raised without antibiotics), is supported by the image of either a farmer or a farm landscape, the colours of faded beige and green further entrench the sentiment of healthy living with the implied meaning of earthiness and wholesomeness.

Both brands also have the luxury of being supported by the behemoth of Loblaws who control the national distribution channel for both product lines and ensure on-shelf presence. In addition, massive promotional campaigns through both traditional and non-traditional media have reinforced the messaging of what each brand represents, possibly creating a cognitive associative effect through its own promotional activities once the consumer is at the point of 
purchase. Further, the difficulty is to disentangle these promotional efforts constructing these ideals (Eckersley, 2006), from actual consumer aspiration to live healthier.

In the increasingly competitive landscape of health-positioned consumer packaged goods, the survival of brands is dependent on their ability to differentiate and attract consumer attention (Underwood, 2002). Mimicking the values and beliefs of a consumer's healthy lifestyle can be a moving target. An important consideration is the holistic nature of packaging design. Individually these elements are far less effective in crafting their story. The efficiency and effectiveness of the design is the combined elements of verbal and visual cues to achieve a particular effect (Orth et al, 2008). But like Bastian mimicry, the entire effectiveness of the system is reliant on more models than mimics to reduce the likelihood of destabilization. If the packaging is created to only mimic the consumer's healthy lifestyle but does not actually hold the same values and beliefs, there is a negative effect, fracturing the relationship between the brand and consumer as trust is diminished (Underwood, 1998). 


\section{LIMITATIONS \& CONSIDERATIONS FOR FUTURE RESEARCH}

Some of the limitations noted could be potential areas for future research. The product selection and category representation was limited to two sub-brands in the Canadian marketplace. These sub-brands represented the protein category from fresh, frozen and further processed manufacturing. Health-positioned products span many categories represented by a large variety of brands. Further contributions to this reserach could include a larger selection from various brand contributors spanning multiple categories to drive a larger sample selection. This would improve trending analysis to determine what elements of packaging design in the health-positioned products in Canada are leveraged most frequently and improve overall statistical accuracy. Additional elements of packaging design could also be incorporated from a material utilization perspective (plastic vs paper) in the category, this would expand the scope of the research to include a more robust understanding of all the levers of design and how it contributes to the overall narrative. Traditional and non-traditional methods of promotion that support these brands could be included for future analysis and how the symbolic representations of health and well-being from the packaging are leveraged on a larger promotional scale.

The limitations of content analysis include the impact of personal bias. Cultural and societal influences through various learned experiences regarding the perception of health can alter these results if duplicated by another researcher. Having at least one other researcher to work through the data would reduce this bias. Personal bias aside, this method for research did provide a sound frequency analysis, but inferences about the use of such elements of design relied heavily on existing research. Perhaps future research could also incorporate a triangulation approach to provide an opportunity for a more in-depth analysis including actual consumer acceptance and / or understanding of the elements of design used. 


\title{
APPENDICES
}

\author{
Appendix A Coding Scheme
}

The following is the coding scheme created for the content analysis of the packaging panels. The intention of this scheme is to provide the context of which each element is to be evaluated and potential scale or examples for evaluation if necessary. The purpose is to increase objectivity in the evaluation for duplication purposes.

\section{Coding Scheme}

\begin{tabular}{|c|c|c|c|}
\hline Question Code & Questions & Response Type & Explanation \\
\hline \multicolumn{4}{|l|}{ Explicit Elements } \\
\hline Nutritional Claim & $\begin{array}{l}\text { Does the package have a } \\
\text { dominate nutritional } \\
\text { claim? }\end{array}$ & yes / no & $\begin{array}{l}\text { a. yes - there is a dominate nutritional health claim } \\
\text { b. no - there is not a dominate nutritional health claim } \\
\text { Nutritional Health Claim - a nutrition claim must meet a } \\
\text { certain criteria as deteremined by CFIA (eg } 20 \% \text { lower fat) }\end{array}$ \\
\hline Claim Position & $\begin{array}{l}\text { Where is the position of } \\
\text { the Dominate Nutritional } \\
\text { Claim? }\end{array}$ & $\begin{array}{l}\text { Vertical } \\
\text { top } \\
\text { middle } \\
\text { bottom } \\
\text { Horizontal } \\
\text { left } \\
\text { middle } \\
\text { right }\end{array}$ & $\begin{array}{l}\text { Vertical } \\
\text { a. top - claim sit in the upper } 50 \% \text { of the package } \\
\text { b. middle - the claim sits around the middle of the package } \\
\text { C. bottom - the claim sits under the middle portion of the } \\
\text { package } \\
\text { Horizontal } \\
\text { a. left } \\
\text { b. middle } \\
\text { c. right }\end{array}$ \\
\hline Canada Farmers & $\begin{array}{l}\text { Does the package claim } \\
\text { 'raised by Canadian } \\
\text { Farmers' }\end{array}$ & yes / no & $\begin{array}{l}\text { a. yes - the claim raised by Canadian farmers on the front } \\
\text { panel } \\
\text { b. no - the claim raised by Canadian farmers is not on the } \\
\text { front panel }\end{array}$ \\
\hline
\end{tabular}




\begin{tabular}{|c|c|c|c|}
\hline $\begin{array}{l}\text { Health } \\
\text { Symbols/claims }\end{array}$ & $\begin{array}{l}\text { Are there any other } \\
\text { health related labelling } \\
\text { symbols or claims on the } \\
\text { front of the package? }\end{array}$ & yes / no & $\begin{array}{l}\text { a. yes - there is at least one other labelling symbol } \\
\text { b. no - there are no other labelling symbols } \\
\text { labelling symbols contribute to the trigger of health in some } \\
\text { way and may or may not be authorized under specific criteria } \\
\text { as determined by the CFIA (organic, fully cooked, no } \\
\text { preservatives etc). }\end{array}$ \\
\hline \multicolumn{4}{|c|}{ Implicit Elements of Packaging } \\
\hline Prominent Colour & $\begin{array}{l}\text { Which are the most } \\
\text { prominent colours on } \\
\text { the package }\end{array}$ & $\begin{array}{l}\text { white, beige (off- } \\
\text { white), yellow, } \\
\text { orange, red, } \\
\text { pink, purple, } \\
\text { blue, green, } \\
\text { brown, black }\end{array}$ & $\begin{array}{l}\text { Check the prominent colour from the list } \\
\text { a. white } \\
\text { b. beige (off-white) } \\
\text { c. yellow } \\
\text { d. orange } \\
\text { e. red } \\
\text { f. pink } \\
\text { g. purple } \\
\text { h. blue } \\
\text { i. green } \\
\text { j. brown } \\
\text { k. black }\end{array}$ \\
\hline Colour Intensity & $\begin{array}{l}\text { The colours on the } \\
\text { package are more than } \\
2 / 3 \text { of the package }\end{array}$ & $\begin{array}{l}\text { dark and/or } \\
\text { intense } \\
\text { light and/or } \\
\text { faded } \\
\text { half and half }\end{array}$ & $\begin{array}{l}\text { a. Dark and/or intense - if the colours on the package strong } \\
\text { b. Light and/or faded - are more muted or washed out, a } \\
\text { softer version of the colour } \\
\text { c. half and half - is there a fairly even mix of the intensity on } \\
\text { the package }\end{array}$ \\
\hline Image & $\begin{array}{l}\text { Does the package utilize } \\
\text { an image }\end{array}$ & yes / no & $\begin{array}{l}\text { a. yes - there is a picture of any kind on the front panel } \\
\text { b. no - there is no image on package }\end{array}$ \\
\hline Product Image & $\begin{array}{l}\text { Is there an image of the } \\
\text { product? }\end{array}$ & yes / no & $\begin{array}{l}\text { a. yes - does the package utilize an image of the food that is } \\
\text { claimed to be in the package } \\
\text { b. no - is the package void of an image }\end{array}$ \\
\hline Human Image & $\begin{array}{l}\text { Is there an image of a } \\
\text { person? }\end{array}$ & yes / no & $\begin{array}{l}\text { a. yes - a picture of a person is on the front panel } \\
\text { b no - there is no picture of a person on the front panel }\end{array}$ \\
\hline Named Person & $\begin{array}{l}\text { Is there a name of a } \\
\text { person or family name } \\
\text { on the package? }\end{array}$ & yes / no & $\begin{array}{l}\text { a. yes - there is a name or family name of a person on pack } \\
\text { b. no - there is no name or family name of a person on pack }\end{array}$ \\
\hline Canadian Location & $\begin{array}{l}\text { Is there a city or } \\
\text { province named on the } \\
\text { package }\end{array}$ & yes / no & $\begin{array}{l}\text { a. yes - there is a name of a city, or province indicated } \\
\text { b. no - these is no name of a city of province indicated }\end{array}$ \\
\hline Flavour Cue & $\begin{array}{l}\text { Is there an image of } \\
\text { flavour cues? }\end{array}$ & yes / no & $\begin{array}{l}\text { a. yes - there is an image of a flavour cue } \\
\text { b. no - there is no image of a flavour cue } \\
\text { Flavour Cue - is an ingredient that triggers a particular flavour } \\
\text { affiliated with the final product composition (eg. An image of } \\
\text { an onion and sour cream and onion chips) }\end{array}$ \\
\hline
\end{tabular}




\begin{tabular}{|l|l|l|l|} 
Nature Image & $\begin{array}{l}\text { Is there an image of } \\
\text { nature? }\end{array}$ & $\begin{array}{l}\text { yes } / \text { no } \\
\text { b. no - if there is no image of nature }\end{array}$ \\
\hline Image health related & $\begin{array}{l}\text { Does the image } \\
\text { communicate } \\
\text { healthfulness in any } \\
\text { way? }\end{array}$ & $\begin{array}{l}\text { yes } / \text { no } \\
\text { (landscape plant, animal) }\end{array}$ \\
\hline
\end{tabular}


Appendix B: President's Choice Blue Menu Front Panel Design Breakdown

The following image is an example of a Presidents Choice Blue Menu packaging panel for

Sirloin Beef Burgers. Identified below is the location of the packaging elements used in the content analysis.

A. Primary nutrition claim $-30 \%$ Less Fat, upper half packaging, centre

B. Additional health symbols or claims - Gluten Free

C. Image - Use of Image, Product Image, Healthy

D. Packaging Colours - Blue / White - 50/50 - Intense Colour, Use of Faded Colour

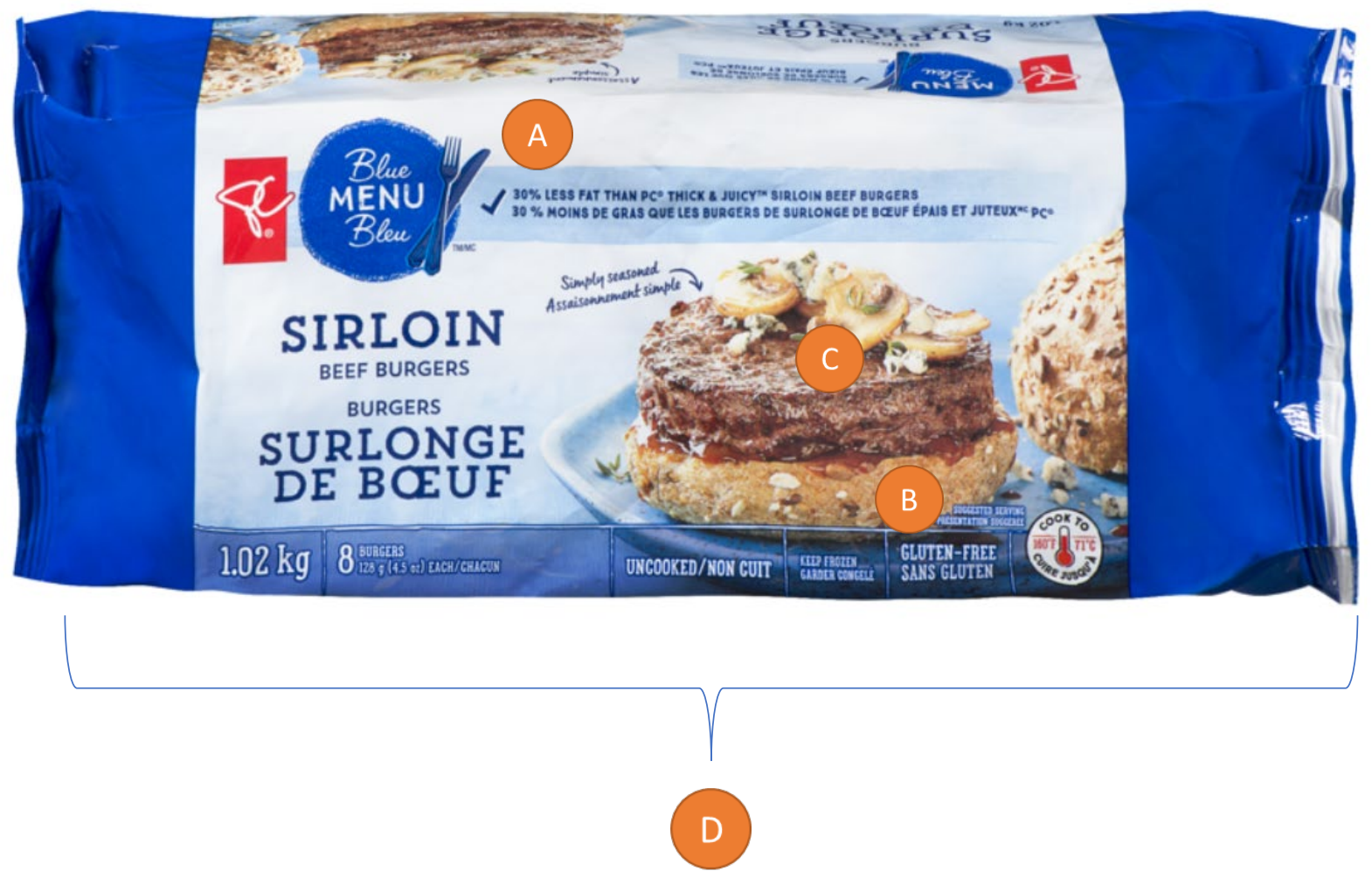


Appendix C: President's Choice Free From Front Panel Design Breakdown - With Landscape Image \& Product Image

The following image is an example of a Presidents Choice Free From packaging panel for Angus

Beef Burgers. Identified below is the location of the packaging elements used in the content analysis.

A. Primary nutrition claim -Raised without antibiotics, upper half packaging, left

B. Additional health symbols or claims - No added hormones, gluten free, no artificial flavour, no artificial colours

C. Image - use of image, product image, landscape image, not healthy

D. Packaging Colours - Green/Beige - faded

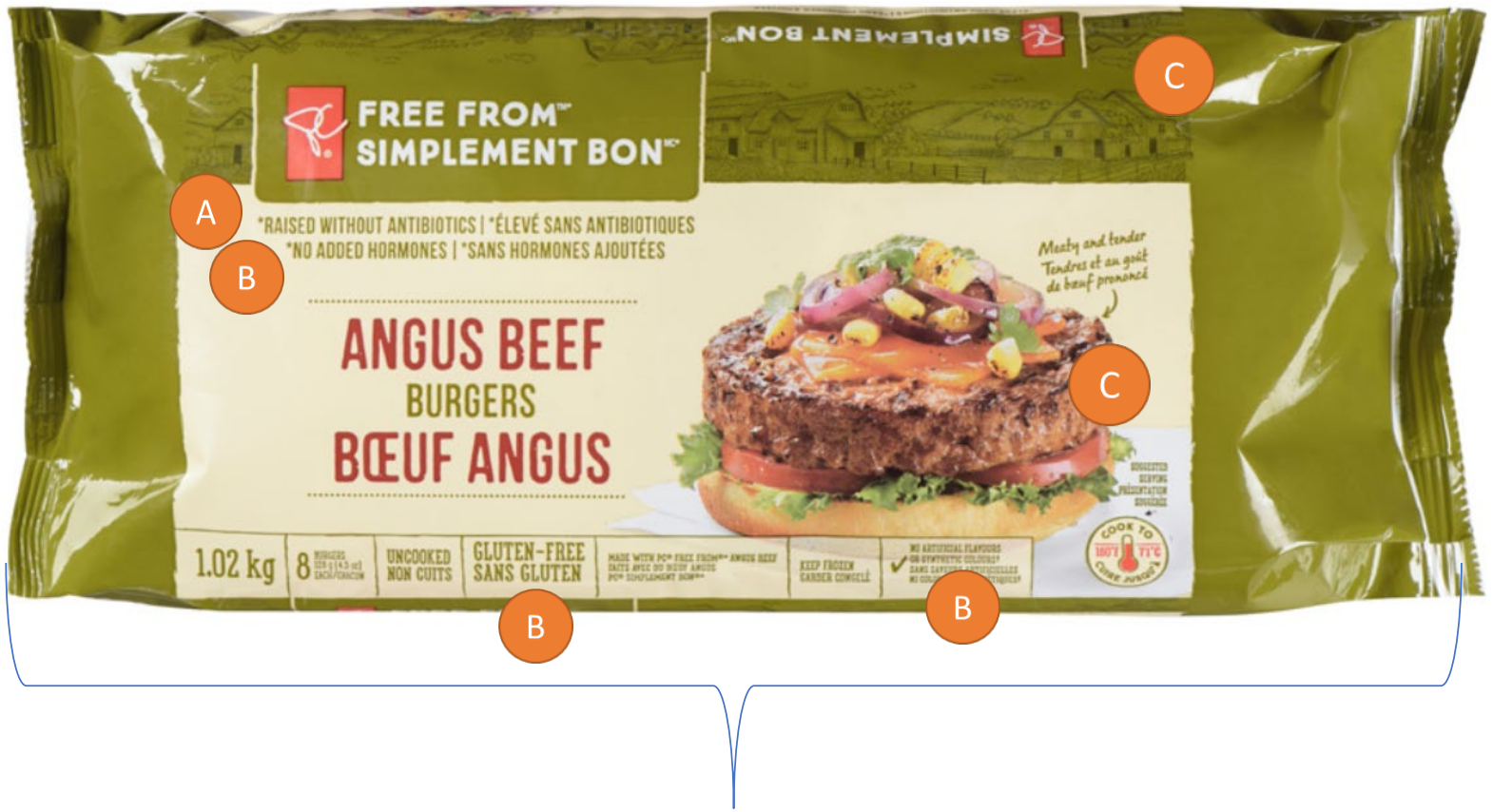


Appendix D: President's Choice Free From Front Panel Design Breakdown - With Human Image

The following image is an example of a Presidents Choice Free From packaging panel for Chicken Breast. Identified below is the location of the packaging elements used in the content analysis.

A. Primary nutrition claim -Raised without antibiotics, upper half packaging, left

B. Additional health symbols or claims - Raised without the use of hormones, like all chicken grain-fed

C. Image - use of image, product image, healthy, human image

D. Packaging Colours - Green/Beige - faded

E. Canadian Farmer Claim

F. Person's Name

\section{FRED FROM" SIMPLDMINAT BON}

A

AISED WITHOUT THE USE OF ANTIBIOTICS

B RAISED WITHOUT THE USE OF HORMONES, IIKE ALL CHICKEN GRAIII-FED

* ÉIEVÉ SANS I'UTIIISATION D'ANTIBIOTIQUES

* ÉLEVÉ SANS I'UTILISATION D'HORMONES, COMME TOUT POULET * NoURri AUX Grains

\section{Chicken Breasts Poitrines de poulet}

$20 \%$ MEAT PROTEIN - SKINLESS, BONELESS, FILLETS REMOVED, SEASONED $20 \%$ DE PROTÉINES DE VIANDE - SANS PEAU, DÉSOSSÉES, SANS FILETS, ASSAISONNEES

\section{3}

WADE WITH PCO PREE FRONE CHICKEH PAISBD BY CATADIAR FARMIBRS

PAIT AVBC DU POULET SIMPLEMENT BOR W: PC ÉLEVŚ PAR DES PRODUCTEURS CAMADIENS

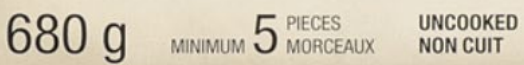
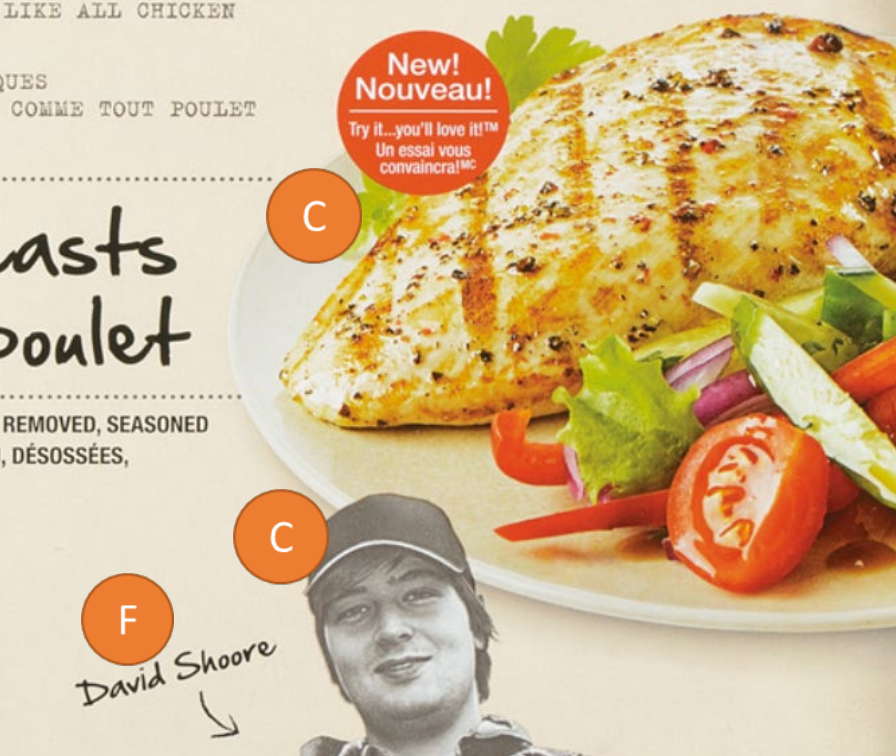


\section{REFERENCES}

Adaval, R., Wyer, R.S., (1998). The role of narratives in consumer information processing. Journal of Consumer Psychology, \&(3), 207-245

Ampuero, O., \& Vila, N. (2006). Consumer perceptions of product packaging. Journal of Consumer Marketing, 23(2), 100-112. https://doi.org/10.1108/07363760610655032

Bacig, M., \& Young, C. A. (2019a). The halo effect created for restaurants that source food locally. Journal of Foodservice Business Research, 22(3), 209-238.

https://doi.org/10.1080/15378020.2019.1592654

Behaeghel, J. (1991). Brand packaging: The permanent medium. Undefined. /paper/Brand-packaging\%3A-the-permanent-medium-Behaeghel/d3403277e6fc39cb6b62bd170e1da6e96608abe0

Bix, L., Sundar, R. P., Bello, N. M., Peltier, C., Weatherspoon, L. J., \& Becker, M. W. (2015). To See or Not to See: Do Front of Pack Nutrition Labels Affect Attention to Overall Nutrition Information? PLoS ONE, 10(10). https://doi.org/10.1371/journal.pone.0139732

Blazquez, Andrea. (n.d.). Grocery stores by size Canada 2020. Statista. Retrieved from https://www.statista.com/statistics/459536/number-of-grocery-stores-by-employment-sizecanadal

Boyle, M. (2003) Brand Killers Store brands aren't for losers anymore. In fact, they're downright sizzling. And that scares the soap out of the folks who bring us Tide and Minute Maid and Alpo and... - August 11, 2003. Retrieved from https:/money.cnn.com/magazines/fortune/fortune_archive/2003/08/11/346850/index.htm

Chrysochou, P., Festila, A, Kulikovskaja, V., (2015) Final_Report_Packaging.pdf. Retrieved from https://pure.au.dk/portal/files/129030011/Final_Report_Packaging.pdf 
Connolly, A. and Davidson, L. (1996), "How does design affect decisions at point of sale?”, Journal of Brand Management, Vol. 4 No. 2, pp. 100-7.

Connolly, J. (2018). Colors that Influence Food Sales. (2018, May 15). Jenn David Design. https://jenndavid.com/colors-that-influence-food-sales-infographic/

Cox, D. T. C., Shanahan, D. F., Hudson, H. L., Fuller, R. A., Anderson, K., Hancock, S., \& Gaston, K. J. (2017). Doses of Nearby Nature Simultaneously Associated with Multiple Health Benefits. International Journal of Environmental Research and Public Health, 14(2), 172. https://doi.org/10.3390/ijerph14020172

Coppola, D, (2021). Grocery retailers market distribution Canada. Statista. Retrieved from https://www.statista.com/statistics/481019/leading-grocery-retailers-by-market-share-canada/ Clement, J. (2007). Visual influence on in-store buying decisions: An eye-track experiment on the visual influence of packaging design. Journal of Marketing Management, 23(9-10), 917-928. https://doi.org/10.1362/026725707X250395

Eckersley, R. (2006). Is modern Western culture a health hazard? International Journal of Epidemiology, 35(2), 252-258. https://doi.org/10.1093/ije/dyi235

Edson Escalas, J. (2004). Narrative Processing: Building Consumer Connections to Brands. Journal of Consumer Psychology, 14(1), 168-180. https://doi.org/10.1207/s15327663jcp1401\&2_19

Edwards-Jones, G., Milà i Canals, L., Hounsome, N., Truninger, M., Koerber, G., Hounsome, B., Cross, P., York, E. H., Hospido, A., Plassmann, K., Harris, I. M., Edwards, R. T., Day, G. A. S., Tomos, A. D., Cowell, S. J., \& Jones, D. L. (2008). Testing the assertion that 'local food is best': The challenges of an evidence-based approach. Trends in Food Science \& Technology, 19(5), 265-274. https://doi.org/10.1016/j.tifs.2008.01.008 
Emmer, M. (2018, July 6). 95 Percent of New Products Fail. Here Are 6 Steps to Make Sure Yours Don't. Inc.Com. https://www.inc.com/marc-emmer/95-percent-of-new-products-fail-here-are-6steps-to-make-sure-yours-dont.html

Festila, A., \& Chrysochou, P. (2018). Implicit communication of food product healthfulness through package design: A content analysis. Journal of Consumer Behaviour, 17(5), 461-476. https://doi.org/10.1002/cb.1732

Fernqvist, F., Olsson, A., \& Spendrup, S. (2015). What's in it for me? Food packaging and consumer responses, a focus group study. British Food Journal, 117(3), 1122-1135. https://doi.org/10.1108/BFJ-08-2013-0224

Garber, L.L., Burke, J.M. And Burke R.R. (2000), The role of package color in consumer purchase consideration and choice, Marketing Science Institute.

Government of Canada, C. F. I. A. (2014a, March 22). Guidelines for Product of Canada and Made in Canada claims - Origin claims on food labels [Fact sheet,guide,reference material]. https://inspection.canada.ca/food-label-requirements/labelling/industry/origin-claims-on-foodlabels/eng/1393622222140/1393622515592?chap $=5$

Government of Canada, C. F. I. A. (2014b, June 10). Food labelling for consumers [Reference material]. https://inspection.canada.ca/food-labelrequirements/labelling/consumers/eng/1400426541985/1400455563893

Grossman, R. P., \& Wisenblit, J. Z. (1999). What we know about consumers' color choices. https://doi.org/10.1108/EUM0000000004565

GuideFoodLabellingAdvertising_CFIA_dec2011.pdf. (2010). Retrieved from http://www.alimentheque.com/divers/GuideFoodLabellingAdvertising_CFIA_dec2011.pdf 
Guy-Evans, Olivia. (n.d.). Lateralization of Brain Function | Simply Psychology. Retrieved from https://www.simplypsychology.org/brain-lateralization.html

Hartig, T., Evans, G. W., Jamner, L. D., Davis, D. S., \& Gärling, T. (2003). Tracking restoration in natural and urban field settings. Journal of Environmental Psychology, 23(2), 109-123. https://doi.org/10.1016/S0272-4944(02)00109-3

Hines, N. (n.d.). Where Greek yogurt actually comes from. Retrieved from https://matadornetwork.com/read/no-greek-yogurt-isnt-greece/

Houston, M. J., Childers, T. L., \& Heckler, S. E. (1987). Picture-Word Consistency and the Elaborative Processing of Advertisements. Journal of Marketing Research, 24(4), 359-369. https://doi.org/10.1177/002224378702400403

Hoyer, W. D. (1984). An Examination of Consumer Decision Making for a Common Repeat Purchase Product. Journal of Consumer Research, 11(3), 822-829.

JohnsByrne. (2017, Feb 16).Packaging Colors: What They Say About Your Brand. (2017, February 16). JohnsByrne. http://www.johnsbyrne.com/blog/packaging-colors-say-brand/

Jones, D. G. B., \& Tadajewski, M. (2016). The Routledge Companion to Marketing History. Routledge.

Karjalainen, T.-M. (2007). It Looks Like a Toyota:Educational Approaches to Designing for Visual Brand Recognition. International Journal of Design, 1(1). http://www.proquest.com/docview/921466398/abstract/5CDCFB4048C54EA9PQ/1

Kassarjian, H. H. (1977). Content Analysis in Consumer Research. Journal of Consumer Research, 4(1), 8. https://doi.org/10.1086/208674

Kauppinen-Räisänen, H. (2014). Strategic Use of Colour in Brand Packaging. Packaging Technology and Science, 27(8), 663-676. https://doi.org/10.1002/pts.2061 
Kauppinen-Räisänen, H., \& Luomala, H. T. (2010). Exploring consumers’ product-specific colour meanings. Qualitative Market Research: An International Journal, 13(3), 287-308. https://doi.org/10.1108/13522751011053644

Killip, B. (1997). Innovative packaging-A marketing must. New Zealand Manufacturer, 12,14. Kirwan, M. J., McDowell, D., \& Coles, R. (Eds.). (2003). Food packaging technology. Blackwell.

Lee, W. J., Shimizu, M., Kniffin, K. M., \& Wansink, B. (2013). You taste what you see: Do organic labels bias taste perceptions? Food Quality and Preference, 29(1), 33-39. https://doi.org/10.1016/j.foodqual.2013.01.010

MacInnis, D. J., \& Price, L. L. (1987). The Role of Imagery in Information Processing: Review and Extensions. Journal of Consumer Research, 13(4), 473-491. https://doi.org/10.1086/209082

Madden, T. J., Hewett, K., \& Roth, M. S. (2000). Managing Images in Different Cultures: A CrossNational Study of Color Meanings and Preferences. Journal of International Marketing, 8(4), 90-107.

Magee, Hannah. (2020, August 6). What is The Health Halo Effect: What is it?? http://hannahmageerd.com/the-health-halo-effect-what-is-it/

Maibach, E. W., Maxfield, A., Ladin, K., \& Slater, M. (1996). Translating Health Psychology into Effective Health Communication: The American Healthstyles Audience Segmentation Project. Journal of Health Psychology, 1(3), 261-277. https://doi.org/10.1177/135910539600100302

Massey, A. (2005) Farm to Table: Building Local and Regional Food Systems. SARE. Retrieved from https://www.sare.org/resources/farm-to-table-building-local-and-regional-food-systems/

Milosavljevic, M., Koch, C., \& Rangel, A. (2011). Consumers can make decisions in as little as a third of a second. Judgment and Decision Making, 6(6), 520. 
Mitchell, V., \& Papavassiliou, V. (1999). Marketing causes and implications of consumer confusion. Journal of Product \& Brand Management, 8(4), 319-342. https://doi.org/10.1108/10610429910284300

Nancarrow, C., Tiu Wright, L., \& Brace, I. (1998). Gaining competitive advantage from packaging and labelling in marketing communications. British Food Journal, 100(2), 110-118. https://doi.org/10.1108/00070709810204101

Neilson (2016). What's in our Food \& On our Mind. Neilson. Retrieved from https://www.nielsen.com/wp-content/uploads/sites/3/2019/04/global-ingredient-and-out-ofhome-dining-trends-aug-2016.pdf

The Nutrition Source (2019, June 24). Processed Foods and Health. The Nutrition Source. https://www.hsph.harvard.edu/nutritionsource/processed-foods/

Orth, U. R., \& Malkewitz, K. (2008). Holistic Package Design and Consumer Brand Impressions. Journal of Marketing, 72(3), 64-81. https://doi.org/10.1509/JMKG.72.3.064

Raghunathan, R., Naylor, R. W., \& Hoyer, W. D. (2006). The Unhealthy = Tasty Intuition and Its Effects on Taste Inferences, Enjoyment, and Choice of Food Products. Journal of Marketing, 70(4), 170-184. https://doi.org/10.1509/jmkg.70.4.170

Rettie, R., \& Brewer, C. (2000). The verbal and visual components of package design. Journal of Product \& Brand Management, 9(1), 56-70. https://doi.org/10.1108/10610420010316339

Rompay, T. J. L. van, \& Veltkamp, M. (2014). Product Packaging Metaphors: Effects of Ambiguity and Explanatory Information on Consumer Appreciation and Brand Perception. Psychology \& Marketing, 31(6), 404-415. https://doi.org/10.1002/mar.20703

Rundh, B. (2016). The role of packaging within marketing and value creation. British Food Journal, 118(10), 2491-2511. https://doi.org/10.1108/BFJ-10-2015-0390 
Kolm, J. (2016, September 27). Brands of the Year 2016: Leader of the pack. Strategy. https://strategyonline.ca/2016/09/27/brands-of-the-year-2016-leader-of-the-pack/

Singh, S. (2006). Impact of color on marketing. Management Decision, 44(6), 783-789. https://doi.org/10.1108/00251740610673332

Smith, K. (2021). Meaning Of Green: Color Psychology And Symbolism. Https://Www.Sensationalcolor.Com/. Retrieved from https://www.sensationalcolor.com/meaning-of-green/

Solja, E., Liljander, V., \& Söderlund, M. (2018). Short brand stories on packaging: An examination of consumer responses. Psychology \& Marketing, 35(4), 294-306. https://doi.org/10.1002/mar.21087

Spence, C. (2016). 1 - Multisensory Packaging Design: Color, Shape, Texture, Sound, and Smell. In P. Burgess (Ed.), Integrating the Packaging and Product Experience in Food and Beverages (pp. 1-22). Woodhead Publishing. https://doi.org/10.1016/B978-0-08-100356-5.00001-2

Stokes, R. C. (1985). The Effects of Price, Package Design, and Brand Familiarity on Perceived Quality. [Ph.D., Purdue University]. Retrieved from http://www.proquest.com/docview/302741393/citation/7CE1DF4EED4846A4PQ/1

Underwood, R. L. (2003). The communicative power of product packaging: Creating brand identity via lived and mediated experience. Journal of Marketing Theory and Practice, 11(1), 62-76. Underwood, R. L., \& Klein, N. M. (2002). Packaging as brand communication: Effects of product pictures on consumer responses to the package and brand. Journal of Marketing Theory and Practice, 10(4), 58-68. 
Underwood, R. L., Klein, N. M., \& Burke, R. R. (2001). Packaging communication: Attentional effects of product imagery. Journal of Product \& Brand Management, 10(7), 403-422. https://doi.org/10.1108/10610420110410531

Underwood, R. L., \& Ozanne, J. L. (1998). Is your package an effective communicator? A normative framework for increasing the communicative competence of packaging. Journal of Marketing Communications, 4(4), 207-220. https://doi.org/10.1080/135272698345762

WHO. (1948). Preamble to the Constitution of WHO as adopted by the International Health Conference, New York, 19 June - 22 July 1946; signed on 22 July 1946 by the representatives of 61 States (Official Records of WHO, no. 2, p. 100) and entered into force on 7 April 1948. The definition has not been amended since 1948 . 